\title{
Perlindungan Hukum Pemegang Hak Cipta Atas Film Impor
}

\author{
Agus Wasita \\ Marketing Communication, Faculty of Economic and Communication, \\ Bina Nusantara University, \\ Jakarta 11480, Indonesia \\ awasita@binus.ac.id
}

\begin{abstract}
Since the enforcement of Law No. 19 Year 2002 on Copyright, in particular film businessmen greatly expect that the government may protect the holders of copyright on films, either domestic produced films or imported films against the practice of film pirating. To improve effectively the protection of copyright, since $29^{\text {th }}$ day of July 2003, the Directorate General of Intellectual Property Right (HAKI) of the Ministry of Justice and Human Rights has appealed shopping centers not to provide any single place for businessmen to sell pirated goods. But the appeal looks running ineffectively, because no legal force being imposed to provide certainty, however the Directorate General of HAKI of the Ministry of Justice and HAM (Human Rights) issued threatening of criminal sanction or civil compensation if the Mall/Plaza management still make any violation on the provisions of prohibition to provide any single place for selling the pirated goods. The arising loss resulted from film pirating actually not only suffers a financial loss for the film businessmen but also the state in this case procured from the tax sector. According to Kompas, the state at least suffered financial loss of 11 trillion as from 2005 procured from value added tax which should be levied by the state of film and song sales. additional information this business scale of pirated films may achieve the turnover of Rupiah billions weekly. It can be imagined what will be made by the perpetrators of film pirating in order that their illegal businesses are not disrupted. However, since the 80s the issue on law enforcement, particularly in upholding and handling the copyright has never been seriously handed and completed. The issue on both parallel import and violation of Law No. 8 of 1992 likewise, especially with regard to the obligation to censor film can not be handled appropriately. Meanwhile, the holders of copyright great do hope the police institution may directly arrest the perpetrators of pirating and processes them until filing claims. But apparently from the cases handled, which may further be processed until filing the claims are some of them only. By virtue of above illustration, the prominent issue to be discussed in this writing is ineffectiveness of legal enforcement of the state against the holders of copyright of imported films. It is alleged for insufficient statutory regulations to solve the complicated problems, obscure rule of games and the officers of legal institution weakly apply the law enforcement.
\end{abstract}

Keywords - Copyrights; Imported Film; Law Enforcement.

\begin{abstract}
ABSTRAK
Sejak berlakunya Undang-undang Nomor 19 Tahun 2002 tentang Hak Cipta, khususnya pengusaha Film sangat berharap bahwa pemerintah dapat melindungi pemegang hak cipta film, baik film yang diproduksi dalam negeri atau film impor, terhadap praktik pembajakan film. Sejak tanggal 29 Juli 2003, Direktorat Jenderal Hak Kekayaan Intelektual (HAKI) Kementerian Hukum dan Hak Asasi Manusia mengimbau Pusat Perbelanjaan untuk tidak memberikan tempat bagi pengusaha untuk menjual barang bajakan termasuk film bajakan, tetapi terlihat tidak berjalan efektif. Meskipun Direktorat Jenderal HAKI Departemen Hukum dan HAM (Hak Asasi Manusia) mengeluarkan ancaman untuk memberikan sanksi pidana atau menggugat secara perdata jika manajemen Mall / Plaza masih membuat pelanggaran atas ketentuan larangan untuk memberikan tempat usaha. Kerugian yang timbul akibat dari pembajakan film sebenarnya tidak hanya pada kerugian keuangan untuk pengusaha Film tetapi juga negara dalam hal ini dari sektor pajak. Sejak tahun 80-an isu penegakan hukum, khususnya dalam menegakkan hukum dan penanganan hak cipta tidak pernah benar-benar serius diselesaikan. Belum lagi masalah
\end{abstract}


pararel impor yang juga melanggar Undang-Undang Nomor 8 Tahun 1992 tentang perfilman, khususnya yang berkaitan dengan kewajiban untuk menyensor film yang tidak dapat ditangani dengan tepat. Sementara itu, pemegang hak cipta berharap institusi kepolisian dapat langsung menangkap pelaku pembajakan dan memproses mereka bahkan sampai penuntutan. Namun ternyata dari kasus yang ditangani, yang selanjutnya dapat diproses sampai penuntutan hanya penjual bajakan saja. Berdasarkan permasalahan di atas, penelitian ini bermaksud memberikan pemahaman tentang perlindungan yang diberikan pemerintah terhadap pengusaha film khususnya pengusaha film impor. Apakah karena peraturan perundang-undangan tidak cukup untuk memecahkan masalah yang rumit, tidak adanya aturan yang jelas atau memang upaya penegakan hukum yang lemah. Penelitian ini merupakan bagian dari penelitian hukum sosiologis, artinya hukum dikonsepkan sebagai pranata sosial yang secara riil dikaitkan dengan variabel-variabel sosial yang lain. Beberapa karakteristik penelitian hukum sosiologis yaitu; mengunakan bahan kepustakaan sebagai data sekunder sebagai data awal, yang kemudian dilanjutkan dengan data primer atau data lapangan. serta hasilnya bersifat kualitatif. Penelitian ini akan difokuskan berdasarkan fakta-fakta yang terjadi, mengujinya dengan sejumlah peraturan yang ada dan realitas dilapangan. Hasil penelitian menunjukan bahwa negara telah melakukan upaya politik hukum yang benar untuk melindungi pengusaha film impor namun memang seperti kasus-kasus hukum lainnya upaya penegakan hukum memang masih menjadi pekerjaan rumah pemerintah yang tidak pernah terselesaikan.

Kata kunci - Hak Cipta; Impor Film; Penegakan Hukum.

\section{PENDAHULUAN}

Sejak refomasi 1998 , dunia perfilman ikut mengalami reformasi, seiring dengan kebijakan Presiden Gus Dur membubarkan Departemen Penerangan, pada tahun 1999. Kebijakan ini mengakhiri peran Pemerintah dalam industri perfilman nasional. Sayangnya, kebijakan politik itu berhenti hanya sampai perubahan instrumental tetapi tidak diikuti dengan visi dan misi yang jelas atas kebijakan perfilman.

Ketika Gus Dur menjadi Presiden, tercatat adanya beberapa perubahan atas kebijakan perfilman di Indonesia. Keputusan Presiden Nomor 153 Tahun 1999 tentang Pembentukan Badan Informasi dan Komunikasi Nasional (BIKN) yang menempatkan film sebagai informasi dan diurus oleh Deputi Bidang Pelayanan Informasi Media Baru dan Perfilman, memberikan kesan akan adanya perubahan itu. Namun tidak berapa lama BIKN dibubarkan, dan diganti dengan Lembaga Informasi Nasional(LIN) sebagai Lembaga Pemerintah Non Departemen. Selanjutnya berdasarkan Keputusan Presiden Nomor 165 Tahun 2000, Presiden memberikan kewenangan kepada Departemen Kebudayaan dan Pariwisata untuk melakukan Penetapan Pedoman Peredaran Film dan Rekaman Video Komersial. Sementara itu, dari segi penataan organisasi, dengan Keputusan Presiden Nomor 177 tahun 2000, Direktorat Jenderal Nilai Budaya, Seni dan Film ditempatkan dalam struktur kelembagaan Departemen Kebudayaan dan Pariwisata. Kebijakan ini sama sekali tidak memperbaiki maupun memberi wajah baru bagi kebijakan perfilman di Indonesia. Dalam hal demikian, upaya Gus Dur membubarkan Departemen Penerangan dan mengakhiri dominasi peran pemerintah dalam industri film tidak mengalami perubahan secara signifikan.

Dalam Era Pemerintahan Presiden Megawati, Departemen Kebudayaan dan Pariwisata berubah menjadi kantor Menteri Negara Kebudayaan dan Pariwisata yang secara umum bertugas membantu Presiden dalam merumuskan kebijakan dan koordinasi di bidang pariwisata dan kebudayaan. Untuk bidang Perfilman, Menteri Negara Kebudayaan dan Pariwisata diberi wewenang untuk menetapkan Pedoman Peredaran Film dan Rekaman Video Komersial. Disamping itu, dibentuk pula Badan Pengembangan Kebudayaan dan Pariwisata sebagai Lembaga Pemerintah Non Departemen yang bertugas memfasilitasi pelaksanaan sensor film dan rekaman video komersial. Berbeda dengan Pemerintahan Rezim Orde Baru maupun Rezim Gus Dur yang menempatkan kewenangan di bidang perfilman dibawah koordinasi Menteri Koordinator Politik dan Keamanan, pada Pemerintahan Megawati kewenangan perfilman ditangan Menteri Negara kebudayaan dan Pariwisata ditempatkan berada dibawah koordinasi Menteri Koordinator Bidang Kesejahteraan Rakyat.

Salah satu kebijakan perfilman masa lalu adalah kecenderungan Pemerintah melihat kebudayaan film sebagai persoalan nasional. Melalui jargon "kebudayaan nasional", film sebagai bagian dari identitas nasional harus dibela, terutama dari pengaruh negatif globalisasi atau pengaruh budaya barat sehingga tak heran jika kebudayaan seringkali dilihat sebagai masalah keamanan yang serius, yang membahayakan kedaulatan, persatuan dan kesatuan bangsa. Sebagai contoh, jaman Orde Baru dulu, masyarakat tidak dapat menonton film dari Rusia atau dari Cina daratan karena berasal dari negara komunis, meskipun film tersebut sama sekali tidak bertemakan tentang ajaran komunis. 
Kebudayaan bukanlah sesuatu yang harus dipertahankan tanpa landasan kebijakan yang jelas dan mendasar. Kebudayaan juga tidak mungkin menjadi wilayah tertutup mengingat kebudayaan merupakan hasil kreativitas dan inovasi masyarakat yang membutuhkan ruang kemerdekaan untuk terus berkembang. Tanpa ruang kemerdekaan, kebudayaan akan mati dengan sendirinya. Ilustrasi nyata ini terlihat pada UU No. 8 Tahun 1992 tentang Perfilman dan peraturan pelaksanaannya yang mensyaratkan sekurang-kurangnya 38 formulir yang harus diisi untuk dapat memproduksi sebuah film hingga proses penayangannya atau pertunjukannya. Alur birokrasi yang berbelit-belit sangat membelenggu kebebasan dan kemerdekaan industri film dalam negeri . Akibatnya, banyak pekerja film yang enggan untuk membuat film dan banyak "pemain film" yang lebih senang menjadi "penonton film".

Sejak refomasi, bidang usaha perfilman dapat dimasuki siapapun sepanjang mengurus perizinan sesuai peruntukannya. Secara rinci bidang usaha perfilman meliputi kegiatan :

1. Pembuatan film ;

2. Jasa tehnik film ;

3. Ekspor film ;

4. Impor film seluloid;

5. Impor rekaman video ;

6. Pengedaran film seluloid impor ;

7. Pengedaran rekaman video impor ;

8. Pengedaran film Indonesia ;

9. Pertunjukan film ;

10. Penayangan film .

Sebelum era reformasi, bisnis impor film dikuasai oleh 2 perusahaan saja, yaitu PT. Suptan Film sebagai importir film khusus berbahasa Mandarin dan PT. Camila Internusa Film sebagai importir film khusus berbahasa Inggris . Pada era reformas saat inii, monopoli bisnis ini berhasil dibuka, dan sampai saat ini terdapat 11 perusahaan importir film. Namun perlu dicatat bahwa 9 perusahaan diantaranya "bergabung" dalam bentuk kepemilikan silang atau kerjasama terselubung yang mengakibatkan terjadinya kembali kepemilikan usaha yang mengarah ke monopoli. Kecenderungan monopoli seperti ini tidak sejalan dengan Undang-undang Anti Monopoli yaitu UU No. 5 Tahun 1999 yang mengatur mengenai posisi dominan dan larangan pelaku usaha melakukan sesuatu yang dapat mendistorsi pasar dan/atau yang dapat mengakibatkan praktik monopoli.

Sejak diberlakukannya Undang-undang Hak Cipta No. 19 Tahun 2002 tentang Hak Cipta, Pengusaha perfilman berharap banyak bahwa Pemerintah dapat melindungi para pemegang hak cipta atas film-film, baik film buatan sendiri (film buatan dalam negri) maupun film yang diimpor dari manca negara terhadap praktek pembajakan film. Harus diakui bahwa pembajakan film, sebenarnya sudah berjalan sejak tahuan 80-an dimana pembajakan film bisa dilakukan di rumah dengan melakukan penggandaan dari betamax ke betamax. Kemudian berkembang teknologi laser disc, Video Compact Disc/VCD sampai yang terakhir dalam bentuk Digital Video Disc/DVD. Pada laser disc yang terjadi bukanlah pembajakan film, tapi yang terjadi adalah parallel import. Khusus masalah parallel import, telah diatur suatu undang-undang dibidang perfilman yaitu Undang-undang No. 8 Tahun 1992 yang mengatur antara lain prosedur atau tata cara usaha perfilman dan tata cara importasi film masuk ke Indonesia. Selain itu diatur pula bahwa setiap film harus disensor terlebih dahulu oleh lembaga sensor. Jika tidak, maka dapat dianggap sebagai pelanggaran hukum. Hal ini diatur dalam UU No. 8 Tahun 1992 tentang Perfilman. Tetapi kenyataannya Laser Disc atau $V C D / D V D$ yang tidak pernah disensor pun sudah bisa beredar hampir diseluruh pelosok Indonesia terutama kota-kota besar seperti Jakarta, Medan, Surabaya dan Makasar.

Untuk meningkatkan efektifitas perlindungan Hak cipta, sejak 29 Juli 2003, Direktorat Jendral Hak Kekayaan Intelektual (HAKI) Departemen Kehakiman dan Hak Asasi Manusia telah menghimbau pusat-pusat pertokoan/ perdagangan untuk tidak menyediakan tempat bagi para pengusaha untuk berjualan barang-barang bajakan. Tetapi sepertinya himbauan itu tidak dapat dilaksanakan, karena tidak ada kekuatan hukum yang memberikan kepastian, meskipun Dirjen HAKI Depkeh dan HAM telah mengeluarkan ancaman sanksi pidana atau ganti rugi secara perdata apabila pengelola Mall/plasa masih melanggar ketentuan larangan menyediakan tempat bagi penjualan barangbarang bajakan. Sebenarnya kerugian yang timbul dari pembajakan film bukan hanya merugikan materi pengusaha film, tetapi juga negara dari sektor pajak. Menurut catatan Kompas, pada tahun 2005 saja, negara sedikitnya dirugikan 11 trilliun dari pajak pertambahan nilai yang seharusnya bisa dipungut negara atas penjualan film dan lagu. 
Namun demikian, sejak tahun 80-an masalah law enforcement, khususnya dalam penegakan dan penanganan hak cipta tidak pernah serius dan tuntas. Demikian pula masalah paralel impor maupun pelanggaran terhadap UU No. 8 Tahun 1992, khususnya kewajiban untuk menyensor film tidak bisa ditangani. Kesemuanya itu membuktikan adanya elemen dalam penegakan hukum yang tidak bekerja maksimal. Sementara itu, para pemegang hak cipta banyak berharap pihak kepolisian dapat langsung menangkap pelaku pembajakan dan memprosesnya hingga penuntutan. Tapi kenyataannnya dari sekian banyak kasus yang ditangani, hanya beberapa saja yang bisa dilanjutkan ketahap penuntutan.

Untuk mengatasi pembajakan, pemerintah tampak seperti kewalahan karena akar permasalahannya tidak pernah diselesaikan, seperti korupsi aparat penegak hukum yang main mata dengan pedagang barang bajakan , tidak adanya penegakan hukum atas pengaturan tentang pabrik optical disc/ disc cakram dan skala bisnis film bajakan ini yang beromzet milyaran rupiah perminggu. Jadi bisa dibayangkan apa yang akan diusahakan pelaku pembajakan film agar pundi-pundi mereka tidak terusik.

Dengan ilustrasi diatas, masalah utama yang akan dibahas dalam penulisan ini adalah seberapa besar perlindungan hukum dari negara terhadap pemegang hak cipta atas film-film impor. Hal ini diduga disebabkan oleh peraturan perundang-undangannya yang belum cukup mengatasi permasalahan yang kompleks, aturan main yang tidak jelas atau law enforcement yang dilakukan aparat penegak hukumnya lemah. Berdasarkan kenyataan tersebut, Penulis akan membatasi pada permasalahan tentang sejauh mana negara memberikan perlindungan hukum terhadap pelaku usaha perfilman khususnya dibidang impor film selaku pemegang hak cipta atas film impor.

\section{METODE PENELITIAN}

Penelitian ini adalah penelitian hukum sosiologis, artinya hukum dikonsepkan sebagai pranata sosial yang secara riil dikaitkan dengan variabel-variabel sosial yang lain. Hukum sebagai gejala sosial yang empiris sifatnya, dikaji sebagai independent variable yang menimbulkan pengaruh dan akibat pada berbagai aspek kehidupan sosial. Beberapa karakteristik penelitian hukum sosiologis yaitu; mengunakan bahan kepustakaan sebagai data sekunder sebagai data awal, yang kemudian dilanjutkan dengan data primer atau data lapangan. serta hasilnya bersifat kualitatif. Penelitian ini akan difokuskan berdasarkan fakta-fakta yang terjadi, mengujinya dengan sejumlah peraturan yang ada dan realitas dilapangan/prakteknya.

Alat pengumpul datanya terdiri dari data sekunder dan primer. Dalam penulisan ini penulis menggunakan data primer berupa pengambilan data langsung di lapangan melalui observasi dan wawancara, pada kesempatan ini penulis mewawancarai PT. Warna Picture Boxindo selaku impotir film dan Kompol Dana suharso selaku penyidik kriminal khusus Polda Metro Jaya sebagai data primer. Untuk mendukung data primer, data sekunder yang digunakan dalam penelitian ini adalah :

1. Bahan/ materi hukum yang diperoleh dari penelitian kepustakaan (library research) berupa data-data dokumen-dokumen hukum, buku-buku hukum.

2. Bahan/ materi hukum yang berupa pendapat hukum dari para ahli hukum, hasil-hasil karya ilimiah dan hasil penelitian para sarjana hukum.

3. Bahan/ materi lain dari berbagai sumber pendukung seperti surat kabar, internet, majalah, tabloid, jurnal hukum bisnis, dan lain sebagainya.

Data primer, yang diperoleh di lapangan (field research) dengan cara pengambilan statement langsung saat melakukan wawacara dengan narasumber atau pihak yang berkompeten, dipakai untuk mendukung data sekunder maupun tersier yang berkaitan dengan permasalahan dalam penelitian ini. Selanjutnya semua data penelitian ini dianalisis secara kualitatif dan kemudian dipaparkan secara deskriptif analisis.

\section{HASIL DAN PEMBAHASAN}

Dalam proses mengimpor film tidak terlepas dari proses pembelian, pembuatan kontrak atau perjanjian lisensi, pelaksanaan perjanjian dan pembayaran, kemudian proses masuknya materi film tersebut ditanah air, dilanjutkan dengan proses produksi alias memperbanyak untuk diedarkan dalam berbagai bentuk format film sampai ditayangkan dan/atau dipertunjukkan ke masyarakat dalam berbagai bentuk media film. 


\section{Proses Pembelian Film}

Proses pembelian film, biasanya dilakukan dengan menyaksikan film yang hendak ditawarkan ditempat khusus yaitu di market film, dimana film-film dari seluruh dunia ditawarkan dan ditayangkan hanya untuk penjualan atau disebut Market premire. Atau dengan hanya menyaksikan cuplikan-cuplikan film yang telah diedit sang produser atau yang disebut trailer. Selain itu, bisa juga dengan hanya membaca sypnopsis atau scripts. Proses pembelian dengan cara yang terakhir disebut juga presale buying, proses pembelian ini dilakukan apabila kita sudah sering membeli film dari produser yang bersangkutan sehingga distributor percaya dengan sang produser tersebut bahwa sang produser memang mampu untuk membuat film-film yang cocok untuk pangsa pasar distributor. Proses pembelian biasanya dilakukan dengan mengunjungi film-film market yang diadakan hampir setiap bulan dan berada dibeberapa manca negara

\section{Proses Kontrak Pembelian Film}

Seperti diungkapkan diatas usaha impor film tidak terlepas dari perjanjian lnternasional yang berbentuk perjanjian lisensi film. Dalam setiap perjanjian lisensi film ada 5 kategori yang dijadikan dasar perjanjian lisensi yaitu ;

\section{a. Basic License Terms}

pada bagian ini termuat ; judul film, wilayah peredaran, waktu lisensi, bahasa yang dari film maksud dan yang akan diizinkan untuk digunakan. Kendala yang terjadi pada bagian ini biasanya adalah pembelian film tidak selamanya 1 film 1 perjanjian, apabila kita membeli 2 atau lebih film sekaligus dari produser yang sama biasanya mereka akan membuat beberapa judul yang dibeli tersebut menjadi satu perjanjian lisensi, kecuali apabila beda wilayah penanyangannya. Hal ini sengaja dilakukan oleh produser apabila film yang ditawarkan memang mengharuskan dengan penjualan secara paket. Apabila distributor dikemudian hari memutuskan untuk tidak melakukan pembelian terhadap seluruh film yang tercantum dalam perjanjian lisensi maka dapat dianggap distributor telah wanprestasi dan semua judul film yang tercantum dalam perjanjiaan tersebut dapat dibatalkan seluruhnya walaupun dalam prosesnya film itu telah diimpor satu per satu judul.

\section{b. Licensed Rights Terms}

Pada bagian ini dimuat, rights apa yang diberikan produser, contoh untuk rights untuk penayangan bioskop, video, televisi berlangganan, televisi teristerial dengan window time masing-masing media penayangan. Produser film dimaksud dapat memberikan haknya hanya untuk media tertentu, contoh media bioskop untuk PT. A lalu untuk video untuk PT. B dan sebagainya. Tetapi bisa juga seluruh hak media penayangan dipegang oleh satu perusahaan.

\section{c. Financial Terms}

Pada bagian ini memuat biaya lisensi minimal/minimum royalty yang harus dibayar perusahaan, cara dan tujuan pembayaran, serta pembayaran selanjutnya. Pada bagian ini dapat dilakukan negosiasi untuk pelisensian film dengan harga tetap tapi bisa pula dengan biaya lisensi minimum. Cara yang kedua sering dipakai oleh produser film yang sangat yakin bahwa filmnya bisa memberikan keuntungan untuk mereka sehingga awalnya mereka bersedia untuk memberikan angka minumum yang harus mereka terima tetapi selanjutnya apabila telah melampaui alokasi lisensi minumum yang telah dibayarkan maka untuk masing-masing media penayangan diharuskan memberikan pembayaran lanjutan yang disebut royalty sesuai dengan prosentase yang telah ditetapkan. Sengketa yang terjadi biasanya karena produser tidak mendapatkan pembayaran selanjutnya yang berupa royalty ataupun pembayaran yang tidak lengkap alias hanya membayar sampai deposit untuk memdapatkan film tersebut tetapi selanjutnya pembayaran atas film tersebut tidak dilunasi. Hal ini biasa terjadi pada pembelian yang berupa presale atau film belum selesai sehingga masih berupa cuplikan-cuplikan atau trailer.

\section{d. Delivery Terms}

Pada bagian ini disebutkan syarat pengiriman barang, waktu pengiriman dan perintah pengiriman. Biasanya pengiriman barang baru dapat dilakukan pada saat pembayaran lisensi minimum telah lunas dilaksanakan. Jadi apabila dalam sebuah perjanjian lisensi terdapat lebih dari 2 judul film sedangkan pembayaran baru dilakukan 1 judul maka pengiriman materi belum dapat dilaksanakan sampai seluruh biaya lisensi diterima penuh oleh sang produser film.

\section{e. Additional Terms.}

Pada bagian ini biasanya dimuat tentang klausul sensor, force majeure, choice of forum, penyelesaian sengketa dan sebagainya. Banyak produser film dari beberapa negara yang mempunyai hubungan bisnis dengan perusahaan 
menggunakan standard term and condition dari American Film Market Association. Untuk menjadi acuan dalam penyelesaian sengketa antara produser dan distributor.

Kendala yang dihadapi importer film adalah masalah Double rights atau kepemilikan ganda. Disebut kepemilikan ganda karena satu film dimiliki oleh dua distributor di dalam negeri. Kepemilikan copyrights/hak cipta atas film seharusnya memiliki hak eksklusif, jadi pada saat terjadi kepemilikan ganda tentu akan membawa dampak mengenai apa yang dianggap sebagai pelanggaran dibidang hak cipta. Penyebab terjadinya kepemilikan ganda pun bervariasi dari lisensor film yang nakal karena menjual hak yang sama kepada dua distributor dari negara yang sama atau dua produser yang berbeda pada saat bersamaan sama-sama mengakui memiliki film yang sama menjual kepada dua distributor yang berbeda dari satu negara yang sama. Karena dasar hukum pembelian lisensi film import adalah perjanjian internasional maka setiap distributor tentu memerlukan pemahaman yang lebih baik terhadap perjanjian internasional dalam mengatasi sengketa double rights/kepemilikan ganda tersebut. Sampai saat ini penyelesaian sengketa atas kepemilikan ganda tidak berjalan sebagaimana mestinya, karena aturan main ditanah air yang tidak jelas, terutama tentang pendaftaran film itu. Saat ini pemerintah melalui badan sensor tidak memeriksa siapa yang mendaftarkan film yang sama, kedua-duanya dapat diterima. Hal ini berbeda dengan sebelum masa reformasi. Satu film hanya boleh didaftarkan sekali, apa bila kemudian ada film yang sama hendak didaftarkan lagi pada masa yang sama sudah pasti akan ditolak dengan demikian tidak pernah terjadi keadaan double rights. Berbeda dengan keadaan sekarang yang membebaskan siapa saja mendaftarkan filmnya meskipun film yang sama dengan masa kepemilikan yang sama pula. Mengenai kemudian ada 2 atau lebih pengusaha lokal yang bersengketa akibat memiliki film yang sama diwaktu yang sama pula, pemerintah mempersilahkan kepada yang merasa berkepentingan untuk mengajukan tuntutannya melalui pengadilan. Proses penyelesaian sengketa yang akan dilakukan oleh pengusaha lokal menimbulkan trauma tersendiri mengingat proses pengadilan di dalam negeri yang begitu "rumit" sehingga apabila mereka menemui kondisi seperti itu biasanya para pengusaha menggunakan cara yang lebih rasional yaitu "musyawarah untuk kata sepakat".

\section{Proses Masuknya Materi Film}

Untuk sebuah film dapat masuk ke tanah air harus dilakukan pendaftaran film terlebih dahulu ke lembaga sensor tetapi lembaga sensor tidak melakukan pengecekan apakah film dimaksud telah dimiliki oleh seseorang di dalam negeri atau tidak, mereka hanya mencatatkan akan masuknya film tersebut. Bahkan jika kemudian film itu tidak jadi dimasukan lembaga sensor yang mencatat pendaftarannya pun tidak pernah mengeceknya. Selanjutnya film yang telah didaftarkan dapat dikirim melalui jasa kurir, membayar biaya pajak impor, pajak pertambahan nilai dan pajak penghasilan. Kemudian film harus disensor sesuai peruntukannya. Contoh film yang berupa pita seluloid harus disensor untuk penayangan bioskop, film yang dimasukan dalam bentuk video harus disensor untuk peredaran video.

Sebenarnya perusahan sudah sejak mula mengimpor beberapa film lepas dalam format video yang dibuat dengan menggunakan tehnologi digital betacam yang cukup baik untuk ditayangkan dilayar lebar tetapi karena terbentur peraturan "kaku" yang dilakukan Lembaga Sensor Film membuat film yang dibuat dalam format video itu tidak dapat dilakukan penyensoran untuk ditayangkan di bioskop. Lembaga Sensor Film tidak dapat melakukan penyensoran film untuk layar lebar (bioskop) dalam format video dikarenakan aturan main yang dipegang lembaga tersebut tidak mengizinkan untuk itu. Tampaknya kemajuan tehnologi digital seperti itu tidak dapat diikuti oleh peraturan yang ada walaupun sebenarnya bioskop digital itu sudah ada sejak dua tahun yang lampau di Amerika Serikat, sudah pula merambah Eropa, Singapura, Thailand dan Filipina dan sejak akhir September tahun 2006 Indonesia sudah pula mulai mempunyai tehnologi bioskop digital yang dilakukan jaringan bioskop baru "Blitz Mega Cineplex". Alasan keharusan berubahnya bioskop konvensional menjadi bioskop digital akan lebih dijelaskan termasuk biaya dibawah ini.

\section{Proses Penggandaan Film}

Yang dimaksud proses produksi disini adalah proses memperbanyak film tersebut untuk diedarkan dalam berbagai format. Film seluloid, sampai saat ini film yang berbentuk pita seluloid belum dapat diperbanyak ditanah air sehingga berapa banyak kebutuhan pita seluloid selalu dipesan kepada produser film dimaksud diluar negeri. Sebagai gambaran, banyaknya jumlah pita seluloid yang dibutuhkan untuk penayangan dibioskop adalah satu berbanding tiga artinya 1 pita seluloid bisa untuk diputar di 3 bioskop yang berbeda dengan selisih waktu penayangan yang berjeda dari 20 menit sampai 60 menit. Harga sebuah pita seluloid baru berkisar USD 900 sampai dengan USD 2000 sedangkan sebuah pita seluloid bekas pakai berharga sekitar USD 400 sampai dengan USD 800. satu-satunya proses produksi atas film seluloid yang dilakukan ditanah air adalah pembuatan subtitle 
atau yang dikenal dengan pembuatan teks terjemahan ke dalam bahasa Indonesia yang dilakukan oleh Badan Sensor Film dengan biaya perjudul sebesar Rp 1.500.000, ditambah biaya sensor atas film itu sendiri sebesar Rp 1.850 .000 / pita seluloid. Film video, film yang diimpor dalam format video betacam lebih mudah untuk diproses perbanyak, karena prosesnya mudah dan biayanya murah, PT. Kreativisi Inticemerlang, anak perusahaan PT. Warna Picture Boxindo memiliki alat yang cukup memadai untuk melakukan editing dan memperbanyak dalam format video betacam pula. Sebagai gambaran, harga kaset baru betacam @ 90 menit sebesar Rp 200.000, biaya copy sebesar Rp 250.000/betacam, biaya subtile sebesar Rp 1.100.000/judul.

Dengan perbedaan biaya yang demikian, dapat dijelaskan bahwa berkembangnya bioskop digital sangatlah efisien dan bermanfaat bagi pengusaha maupun pemakai jasa hiburan tersebut. Di bawah ini, dirincikan perbedaaan biaya yang terjadi apabila sebuah film itu dimasukan dalam bentuk pita seluloid atau dalam bentuk format video.

\begin{tabular}{llll}
\multicolumn{1}{l}{$\boldsymbol{S E L \boldsymbol { L } \text { OID }}$} & & \\
\hline MATERI 35MM FEATURE & & USD 1,600 & untuk 1 copy \\
\hline MATERI 35MM TRAILER & & USD 100 & untuk 1 copy \\
\hline BIAYA PENGIRIMAN & PAJAK & Rp. 2.500.000,- & untuk 1 copy \\
\hline SENSOR & & Rp. 3.000.000,- & untuk 1 copy \\
\hline & PENDAFTARAN & Rp. 150.000,- & untuk 1 copy \\
\cline { 2 - 4 } & SUBTITLE & Rp. 1.500.000,- & untuk 1 copy \\
\cline { 2 - 4 } & SENSOR & Rp. 1.700.000,- & untuk 1 copy \\
\hline TOTAL BIAYA UNTUK 1 COPY & Rp. 25.700.000,- & \\
\hline
\end{tabular}

\begin{tabular}{llll}
\multicolumn{1}{l}{ VIDEO / DIGITAL } & & \\
\hline MATERI BETACAM & & USD 500 & untuk 1 judul \\
\hline BIAYA PENGIRIMAN & Rp. 500.000,- & untuk 1 judul \\
\hline PENAK & Rp. 350.000,- & untuk 1 judul \\
\hline & & & \\
\cline { 2 - 4 } & PENDAFTARAN & Rp. 150.000 & untuk 1 judul \\
\cline { 2 - 4 } & SUBTITLE & Rp. 1.500.000,- & untuk 1 judul \\
\cline { 2 - 4 } & SENSOR & Rp. 200.000,- & untuk 1 judul \\
\hline TOTAL BIAYA UNTUK 1 JUDUL & Rp. 7.700.000,- & \\
\hline
\end{tabular}

Contoh;

- Biaya copy materi betacam/digital adalah Rp. 450.000,- per copy.

- Untuk membuat 9 copy betacam/digital adalah : 9 x Rp. 450.000,- = Rp. 4.050.000,-

- Ditambahkan dengan biaya pembuatan copy pertama / master copy sebesar Rp. 7.700.000,- (seperti pada tabel di atas), total biaya untuk 10 copy betacam/digital menjadi Rp, 12.150.000,-

- Bandingkan dengan biaya yang harus dikeluarkan untuk pengadaan 10 copy film seluloid sebesar 10 copy x Rp. 25.700.000,- menjadi total Rp. 257.000.000,-.

- Perbandingan biaya yang harus dikeluarkan untuk pengadaan seluloid dengan betacam/digital adalah 20: 1, atau dapat dikatakan biaya dengan betacam/digital hanya 5\% dibandingkan biaya dengan seluloid.

Berdasarkan biaya-biaya yang harus dikeluarkan diatas dapat dijelaskan bahwa biaya yang dikeluarkan untuk memproses sebuah film untuk ditayangkan dibioskop akan lebih efisien dalam format video betacam. Namun perlu digarisbawahi disini adalah sampai penulisan ini dibuat, Pemerintah melalui Badan Sensor Film belum dapat melakukan penyensoran film untuk bioskop yang akan mengunakan format digital. Badan Sensor Film hanya menerima penyensoran dengan mengunakan materi konvensional yaitu film dalam bentuk pita seluloid, Hal ini disebabkan aturan pelaksanaan dari atas belum ada. Hal ini merupakan kendala yang sangat menggangu kegiatan importir film dalam usahanya menekan harga produksi. Video compact disc/ Digital video disc, film yang diimpor untuk diedarkan dalam bentuk VCD maupun DVD, dimasukkan dalam format video betacam sebagai masternya. Biaya yang dikeluarkan untuk biaya produksi master copy sama dengan biaya yang dikeluarkan dengan biaya film dalam format video betacam. 
Biaya selanjutnya adalah biaya pembuatan VCD dan DVD itu sendiri. Biaya pembuatan VCD/DVD adalah :

1.VCD@ Rp.1.500,- perkeping, setiap judul perlu 2 keping, total Rp. 3000,- DVD@ Rp.9.000,perkeping. Sebuah film perlu 1 keping.

2. Biaya cover Rp. 1.500,- box Rp.1.000,- biaya pengepakan Rp. 500,-

3. Biaya PPN

\begin{tabular}{|c|c|c|c|}
\hline VIDEO & & Pajak & Pajak dari Harga Jual per unit \\
\hline Jenis I & $\mathrm{Rp}$ & $1,000,-$ & Harga Label Kurang Rp. 10.000,- \\
\hline Jenis II & $\mathrm{Rp}$ & $1,250,-$ & Harga Label Rp. 10.000,- s/d Rp. 20.000,- \\
\hline Jenis III & $\mathrm{Rp}$ & $2,500,-$ & Harga Label Rp. 20.000,- s/d Rp. 40.000,- \\
\hline Jenis IV & $\mathrm{Rp}$ & $4,750,-$ & Harga Label Rp. 40.000,- s/d Rp. 60.000,- \\
\hline Jenis $\mathrm{V}$ & $\mathrm{Rp}$ & $6,500,-$ & Harga Label Rp. $60.000,-$ s/d Rp. 80.000,- \\
\hline Jenis VI & $\mathrm{Rp}$ & $8,500,-$ & Harga Label Rp. 80.000,- s/d Rp. 100.000, \\
\hline Jenis VII & $\mathrm{Rp}$ & $15,000,-$ & Harga label lebih dari Rp. 100.000,- \\
\hline
\end{tabular}

Total biaya langsung yang dikeluarkan untuk VCD adalah Rp. 6.000,- sedangkan untuk DVD Rp.12.000, Dipasaran gelap sebuah film dalam bentuk VCD bajakan dijual dengan harga Rp. 4.000,- - Rp. 5.000,- tanpa box sedangkan DVD dijual dengan harga Rp. 5.000,- - Rp. 8.000,- perjudul tanpa box.

Kendala dalam proses ini terjadi saat dilakukan perbanyakan sebuah film dalam format VCD dan DVD. Proses memperbanyak VCD/DVD dilakukan oleh pabrik yang khusus memiliki perizinan pembuatan cakram optik. Tetapi sudah menjadi rahasia umum, kalau pabrik cakram optik itu kadangkala ada yang berbuat nakal, yang juga sebagai pembajak film. karena dari merekalah film-film yang berbentuk VCD dan DVD itu dicetak. Pemegang Hak Cipta atas film tidak dapat mengkontrol jumlah VCD dan DVD yang benar-benar dicetak oleh pabrik. Contoh, perusahaan pemegang Hak Cipta atas film melakukan pesanan untuk mencetak sebanyak 2000 keping per judul, tetapi siapa yang dapat mengkontrol pabrik untuk mencetak hanya sesuai pesanan pemegang hak cipta film. Bisa saja pabrik melaporkan cetakan sebanyak 2000 keping sesuai pesanan tetapi sebenarnya pabrik mencetak 5000 keping sehingga kelebihan 3000 keping itu diedarkan melalui pasar gelap dan keuntungan atas peredaran 3000 keping VCD/DVD itu murni menjadi kelebihan pendapatan pabrik. Ini adalah salah satu bentuk dari pembajakan film.

\section{Proses Distribusi \\ Film Seluloid,}

Film seluloid di distribusikan melalui jaringan Bioskop 21, namun dikarenakan jaringan Bioskop 21 merupakan satu-satunya jaringan bioskop yang berskala besar dan mencakup wilayah secara nasional maka para pengusaha impor film seperti kambing yang digembalakan pengembalanya, apa maunya empunya bioskop harus dituruti. Artinya jadwal penayangan akan sangat tergantung "kemurahan hati" empunya bioskop. Diluar daripada itu jaringan Bioskop 21 selain menjadi penayang film juga sebagai pengimpor film (bahasa awamnya toko yang punya pabrik), jadi dengan demikian apa yang dimaksudkan dengan pengusaha yang mengusai bisnis dari hulu ke hilir berlaku di bisnis ini. Sudah pasti pemilik jaringan Bioskop 21 tersebut akan mendahulukan film-film yang mereka impor sendiri. Pada bagian awal disebutkan bawah dari 11 perusahaan pengimpor film, 9 diantara saling terkait dan menjadi satu. Hal tersebut terjadi karena film yang diproduksi dunia sedemikian banyak dan harganya tidaklah murah. Sebagai ilustrasi sebuah film impor dengan bintang "Nicholas Cage" akan membutuhkan biaya kurang lebih USD 400.000 sebagai biaya lisensi minimum bisa dibayangkan apabila dalam satu tahun ada 20 film besar sekelas diatas, total $\mathrm{Rp}$ 80.000.000.000 yang harus dikeluarkan untuk biaya lisensi minimum saja. Sehingga dapat dimengerti mengapa akhirnya mereka memutuskan bergabung. Perusahaan Warna Picture Boxindo termasuk perusahaan yang memutuskan untuk tidak ikut bergabung kedalam "kebersamaan" mereka karena menurut perusahaan, syarat-syarat yang diajukan untuk bergabung sangatlah mematikan kreativitas dan membelenggu independensi perusahaan. 


\section{Film dalam format video untuk televisi,}

Dengan bertambah banyaknya stasiun televisi seharusnya menjadikan pasar film impor menjadi lebih luas akan tetapi kenyataannya berbeda dilapangan. Dari sekian banyak televisi nasional yang benar-benar menguasai pangsa pasar iklan tidak lebih dari setengah jumlah televisi nasional yang ada. Akibatnya hanya sebagian kecil televisi nasional pula yang mampu membeli hak penayangan film asing. Bahkan dengan berlakunya Undangundang penyiaran tentang keharusan menjadi televisi lokal membuat kemampuan stasiun televisi untuk membeli film-film impor menjadi sangatlah terbatas. Belum lagi ditambah dengan kepemilikan silang beberapa stasiun televisi seperti TRANS Corp memiliki Trans 7 dan TRANS TV, RCTI memiliki keterkaitan kepemilikan dengan MNV TV, GLOBAL TV, lalu ANTV dengan TV One. Sehingga dalam setiap kontrak penanyangan di cantumkan film-film yang dilisensikan dapat ditayangkan pula di stasiun televisi yang memiliki afiliasi dengan pihak stasiun televisi yang membeli.

\section{Film dalam format video untuk VCD/DVD,}

Distribusi film dalam format video berupa VCD/DVD sebelumnya dilakukan sendiri oleh perusahaan dengan melakukan kerja sama titip jual dengan beberapa distributor nasional seperti "Disc Tara" atau beberapa distributor besar di daerah tetapi ternyata perusahaan mengalami kendala dalam penagihan. Prosentase keuntungan yang ditawarkan dengan memberikan 30\%-35\% dari harga jual seringkali tidak membuat penjualan meningkat bahkan cenderung stagnan ditambah kesulitan melakukan penagihan, sehingga kemudian perusahaan memutuskan untuk melakukan jual beli putus dengan beberapa distributor menengah untuk menangani penjualan diseluruh Indonesia.

Sebenarnya film dalam format video dibedakan atas video untuk rental/disewakan atau untuk sekali pembelian/jual putus. Tetapi aturan main di tanah air tidak mempunyai aturan yang jelas yang membedakan hal tersebut. Yang mana seharusnya harga sebuah video untuk yang direntalkan dibandingkan yang diperuntukan pemakaian rumahan lebih mahal 4-5 kali lipat dari harga video biasa dikarenakan bisnis rental mengurangi penjualan putus. Tetapi ditanah air sulit diterapkan aturan main seperti itu akibatnya, banyak bermunculan rental rental video baik rental resmi maupun rental tidak resmi. Dikatakan rental resmi karena rental video tersebut menyewakan video-video legal seperti Ultra Disc, Eazy dan lain-lain. Disebut tidak resmi karena selain tidak hanya menyewakan video legal juga menyewakan video bajakan.

Sebenarnya pangsa pasar video ini sangatlah besar dan prospektif tetapi juga bukan rahasia lagi kalau kendala terbesar dari bisnis impor film ini adalah pembajakan film. Masalah utama yang dihadapi perusahan diproses ini adalah Pembajakan film dan masuknya Video Pararel impor. Film-film perusahaan selaku pemegang lisensi dibajak dan diedarkan dalam bentuk DVD oleh orang yang tidak memiliki hak untuk itu. Mereka menawarkan DVD bajakan tersebut dengan harga murah dan kualitas yang bisa diterima, sehingga mengakibatkan kerugian besar bagi pengimpor film tersebut. Saat ini harga sekeping film DVD bajakan sebesar Rp 5.000 - Rp 8.000 sedangkan harga DVD Pararel Import sebesar Rp 20.000 - Rp 30.000. Selama ini perusahaan telah mencoba untuk melakukan beberapa variasi harga penjualan atas DVD original yang dikeluarkan perusahaan, mulai dari $\mathrm{Rp}$ 90.000 untuk pertama kalinya perusahaan mencetak sendiri DVD tetapi karena tidak laku maka harga diturunkan menjadi Rp 75.000 , kemudian Rp 49.000 sampai terakhir Rp 26.000 perkeping DVD original. Tetapi penurunan harga yang dilakukan perusahaan tetap tidak mengakibatkan naiknya jumlah penjualan. Karena selain harga yang lebih mahal, perusahaan juga kalah diwaktu peredaran video, dimana perusahaan harus mengikuti aturan main yang ditetapkan produser mengenai "window time". Contoh, film A diedarkan di negara pembuatnya pada bulan Januari, tetapi karena perusahaan bukan "inner circle" dari group 21, maka film tersebut baru bisa diedarkan di Indonesia paling cepat di bulan Juni di tahun yang sama. Maka dengan window time 6 bulan yang ditetapkan produser, film tersebut baru bisa diedarkan dalam bentuk video paling cepat dibulan Desember, tepat satu tahun setelah film tersebut di edarkan di negara pembuatnya, jadi sudah pasti film bajakan tersebut telah beredar luas di seluruh tanah air.

Perusahaan sudah berulang kali bekerja sama dengan pihak kepolisian melakukan penegakan hukum terhadap para pedagang VCD/DVD yang banyak berusaha dibawah naungan Mal-mal ITC. Tetapi proses penegakan hukum yang dimulai dari pelaporan polisi, pemeriksaan saksi, sampai penggerebekan itu sendiri memakan waktu lebih dari 2 bulan bahkan kadang bisa sampai 6 bulan baru dilakukan razia terhadap para pedagang VCD/DVD tersebut. Biaya yang dikeluarkan untuk penegakan hukum sangatlah tidak sebanding dengan efektivitas yang hendak dicapai dari upaya penegakan hukum itu sendiri sehingga membuat perusahaan agak pesimis untuk bisa mengeruk keuntungan dari bisnis video. 


\section{Film dalam format video untuk televisi berlangganan ataupun media lainnya.}

Pendistribusian film untuk media televisi berlangganan maupun media lainnya tidak lah terlalu signifikan bagi pasar film impor di tanah air, hal ini disebabkan tidak banyaknya televisi berlangganan yang ada ditanah air sehingga harga yang ditawarkan sangatlah kecil, berkisar USD 100 - USD 300 per judul film untuk masa lisensi 6 bulan sampai 12 bulan. Sedangkan untuk media lain seperti hotel, kapal, pesawat, atau angkutan masal lainnya belumlah berjalan seperti yang diharapkan karena mereka tidak terlalu menghargai hak kekayaan intelektual atas film yang diimpor perusahaan walaupun film yang ditayangkan, dibeli resmi atau video legal yang memang banyak beredar dipasaran. Tetapi peruntukannya bisa dikatakan menyalahi aturan main dalam bisnis film impor .

Rangkuman Kendala yang dihadapi Importir Film

\begin{tabular}{lll}
\hline No. & Tahapan Kegiatan & \multicolumn{1}{c}{ Kendala Yang Timbul } \\
\hline 1 & Proses Pembelian Film & $\begin{array}{l}\text { Siapapun (importir film, pengusaha bioskop/ stasiun televisi bahwa orang } \\
\text { pribadi) bisa membeli film asing } \\
\text { Bisnis padat modal }\end{array}$ \\
\hline 2 & Proses Kontrak Pembelian & Adanya kemungkinan Produser nakal \\
& Isi perjanjian lisensi berat sebelah \\
\hline 3 & Proses Masuknya Film & konsisten \\
& Penelitian suatu film pada sat pendaftaran tidak diberlakukan lagi
\end{tabular}

Biaya penggandaan materi untuk penayangan film seluloid yang tinggi.

Solusi alternatif untuk menekan biaya tinggi penggandaan film seluloid dengan

4 Proses Penggandaan Film materi digital, tidak bisa dilakukan segera karena Lembaga Sensor Film belum mempunyai petunjuk pelaksanaan untuk menyensor materi dalam bentuk digital untuk keperluan penayangan di bioskop.

Kemungkinan pembajakan film yang dilakukan pabrik pencetak cakram disc pada saat film tersebut digandakan dalam bentuk VCD/DVD

Pengusaha bioskop sekaligus importir film, mengakibatkan importir film independen tidak mempunyai "bargaining power" terhadap jadwal penayangan bioskop.

$5 \quad$ Proses Distribusi Film

Maraknya peredaran video bajakan di pusat-pusat perdagangan seperti mal/ plasa, tanpa penegakan hukum terhadap mal/plasa yang bersangkutan.

Penegakan hukum yang tebang pilih terhadap pabrik pembajak film dengan distributor penjual film bajakan dan/atau toko-toko penjual film bajakan

\section{KESIMPULAN}

1. Perjanjian lisensi Hak Cipta atas film impor adalah perjanjian perdata yang dilakukan oleh 2 atau lebih pihak swasta yang berbeda domisili dan kewarganegaraannya yang bersama-sama karena kecakapannya, dan itikad baik bersepakat untuk membuat perjanjian lisensi film dimana salah satu pihak memberikan lisensi atau hak milik atas suatu film miliknya secara terbatas dan pihak lainnya menerima lisensi tersebut dengan memberikan kompensasi .

2. Perjanjian lisensi Hak Cipta atas film impor adalah perjanjian perdata internasional, distributor sebagai 
penerima lisensi mempunyai kewajiban untuk membaca dan memahami isi perjanjian sebelum menandatangani perjanjian lisensi film tersebut. Selama perjanjian belum ditandatangani, kedua belah pihak mempunyai ruang yang cukup untuk bernegosiasi sesuai harapan kedua belah pihak. Tetapi setelah perjanjian ditandatangani maka kewajiban kedua belah pihak pula untuk mentaati dan menjalankan segala konsekwensi yang ada pada perjanjian tersebut. Apabila dikemudian hari muncul masalah yang terjadi antara produser film yang memberikan lisensi dan distributor yang menerima lisensi, keduanya harus menyelesaikan sengketa diantara mereka sesuai dengan pilihan penyelesaian sengketa yang sudah disepakati didalam perjanjian lisensi tersebut.

3. Adapun cara-cara yang paling efektif dalam menyelesaikan sengketa perjanjian lisensi film antara produser dan distributor adalah negosiasi, dan arbitrase. Penyelesaian sengketa melalui pengadilan nasional sangat tidak dianjurkan karena selain memakan waktu yang lama dan sulit diimplementasikan.

4. Demikian pula masalah yang terjadi dalam pendistribusian film antara distributor yang satu dengan distributor lainnya didalam negeri, hal ini juga merupakan masalah perdata yang bisa diselesaikan dengan cara-cara yang biasa dilakukan orang film dalam menyelesaikan sengketa kepemilikan ganda, yaitu negosiasi atau arbitrase.

5. Dalam hal timbul sengketa antara beberapa pembeli Hak Cipta yang sama atas suatu Ciptaan, perlindungan negara diberikan kepada pembeli yang terlebih dahulu memperoleh Hak Cipta itu. Dengan ketentuan ini, suatu film yang telah dipesan bisa diperiksa terlebih dahulu apakah sudah dimiliki pihak lain ditanah air atau tidak. Apabila sudah ada maka calon pembeli film tersebut bisa mempunyai kesempatan untuk mengambil langkah-langkah yang diperlukan sebelum film itu dibayar.

6. Kepemilikan ganda atas film yang sama dapat menjadi sengketa diantara 2 distributor yang sama ditanah air karena kelemahan pengaturan tehnis operational yang dilakukan oleh pemerintah yang tidak menjalankan tata cara pendaftaran film secara konsisten dan melakukan penelitian atas pendaftaran film tersebut.

7. Pemerintah sudah berupaya maksimal melalui perangkat peraturan perundang-undangan untuk melindungi pengusaha perfilman khususnya importir film. Apabila disana sini masih ditemukan kendala-kendala dalam menjalankan usaha impor film ini lebih disebabkan pada tataran operasional penegak hukum yang belum efisien dan memanfaatkan peraturan perundangan yang dimiliki secara maksimal untuk menindak pelanggaran dan kejahatan tindak pidana yang berkaitan dengan perfilman. Dengan adanya dua Undang-undang (UU Hak Cipta No. 19 tahun 2002 dan UU perfilman No. 8 Tahun 1992) yang dapat dipakai sebagai perlindungan hak cipta di bidang perfilman, maka seharusnya tidak akan ada pembajakan di bidang perfilman. Bahkan Undangundang No. 19 Tahun 2002 ini jauh lebih sempurna dibanding UU Hak Cipta sebelumnya yang telah direvisi serta adanya sanksi hukuman pidana yang merupakan momok bagi para pembajak.

8. Penerapan Undang-Undang Hak Cipta no. 19 Tahun 2002 belum dapat melindungi pengusaha dari tindak pidana pembajakan film. Hal tersebut dikarenakan;

a. Budaya Hukum

Pembajakan film yang terjadi bukan karena faktor harga melainkan dari kesadaraan masyarakat ditanah air terhadap hak kekayaan intelektual atas sebuah film, masih rendah. Masyarakat tidak membenci film bajakan seperti membenci suatu kejahatan umum.

b. Penegakan hukum

Apabila kita amati perkembangan pembajakan film pada saat ini hal ini terjadi karena penegakan hukum yang dilakukan oleh aparat penegak hukum dalam hal ini pihak kepolisian tidaklah dijalankan secara menyeluruh dan tuntas, atau dengan kata lain dijalankan dengan setengah hati sehingga tidak ada satu kasus pembajakan dibidang perfilman yang dapat dipakai sebagai suatu yurisprudensi. Sikap aparat penegak hukum yang menegakkan hak kekayaan intelektual dibidang hak cipta film terutama film impor, tidak memadai. Polisi, Jaksa dan Hakim yang bertugas dilapangan sebagaian besar tidak mengenyam pendidikan lanjutan tentang hak kekayaan intelektual sehingga mereka cenderung "learning by doing" belajar bersamaan pada saat penanganan kasus. Para aparat penegak hukum cenderung masih berkutat pada konsep pemikiran yang lama bahwa pembajakan film masih sama dengan pembajakan barang atau merek, ada yang asli dan ada yang palsu sedangkan didalam pembajakan hak cipta atas film, tidak selalu konotasinya asli atau palsu. Akibatnya aparat penegak hukum sering tidak konsisten menerapkan pidana pembajakan film dengan menggunakan sanksi pidana yang lebih rendah terhadap pengedar/penjual film bajakan dengan mengunakan Pasal 40 Undang-undang No. 8 Tahun 1992 tentang Perfilman yaitu, mengenai film yang tidak disensor. 


\section{DAFTAR PUSTAKA}

Damian, E. (2005). Plagiat dan Pembajakan sebagai Pelanggaran Hukum Hak Cipta. Indonesian J. Int’1 L., 3, 195. Kurniadi, D. (2005). Perlindungan hak cipta atas format program televisi (Doctoral dissertation, FH-UI).

Marpaung, L. (1995). Tindak pidana terhadap hak atas kekayaan intelektual. Sinar Grafika.

Purba, A., Saleh, G., \& Krisnawati, A. (2005). TRIPs-WTO \& hukum HKI Indonesia: kajian perlindungan hak cipta seni batik tradisional Indonesia. Rineka Cipta.

Riswandi, B. A., \& Syamsudin, M. (2004). Hak Kekayaan Intelektual dan Budaya Hukum. Divisi Buku Perguruan Tinggi, RajaGrafindo Persada.

ROOSENO, R. (2002). Perjanjian Lisensi Hak Cipta Musik Dalam Pembuatan Rekaman (Doctoral dissertation, program Pascasarjana Universitas Diponegoro).

Saidin, H. (2015). Aspek Hukum Hak Kekayaan Intelektual, edisi Revisi. Jakarta, PT RajaGrafindo Persada.

Sembiring, S. (2002). Hak kekayaan intelektual dalam berbagai peraturan perundang-undangan. Yrama Widya.

Subekti, R. (1991). Hukum pembuktian. Pradnya Paramita.

Syahmin, A. K. (2006). Hukum Kontrak Internasional. Rajagrafindo Persada.

Yuhassarie, E. (2004). Hak Kekayaan Intelektual dan Perkembangannya. Pusat Pengkajian Hukum, Jakarta.

Jurnal Hukum bisnis (2011). Perlindungan konsumen: hukum dan faktanya. Jakarta., 30(1). 